\title{
LEARNERS' AND THEIR TEACHER'S EXPERIENCES OF AN AUTHENTIC ONLINE ASSESSMENT TEST IN THE UNDERSTANDING OF BASIC ACCOUNTING CONTENT KNOWLEDGE
}

\author{
Rabaitse Diseko ${ }^{1 *}$ and Wendy Modiba² \\ ${ }^{1}$ Dr., University of Johannesburg, South Africa, rdiseko@uj.ac.za \\ ²University of Johannesburg, South Africa, modibawendy@gmail.com \\ ${ }^{*}$ Corresponding author
}

\begin{abstract}
Accounting as a school subject provides a foundation for understanding the economic activities and conditions of a business, it serves as a common language both within the business and for communicating business information to the external financial community. When learners grasp the key financial transactions as well as the analysis, interpretation and communication of financial statements, they are able to understand the fundamental concepts of basic accounting principles and practice. However, there is a lack of adequate preparation at school level in accounting. Learners are taught how to do accounting, but the principles and reasons for accounting, that is, the basic concepts of accounting, are not adequately taught and assessed (Steenkamp, Baard \& Frick, 2010). As a result, South African learners' performance in the subject is poor. We contend that teachers contribute to poor performance because they have inadequacies in their own content knowledge of the subject (Ozden, 2008), as they were not properly trained and equipped to teach it competently (Letshwene, 2014). They also employ inadequate assessment techniques in the subject by using a traditional paper-based approach (Ngwenya \& Maistry, 2012). As a way of supporting teachers in their teaching practice, the Department of Education has formulated assessment guidelines that prescribe an alternative form of assessment that can be completed electronically, using online assessment to gauge learners' understanding of content knowledge of any topic. The usefulness of an online assessment tool is measured in terms of how it reveals the understanding and content knowledge of learners in a meaningful social context. Thus, the aim of this paper is to report on the design of an authentic online assessment of grade 10 learners' and their teacher's understanding of basic accounting content knowledge. QuestBase software was used in the design of online assessment embedded within the theoretical constructs of authentic learning, and with the first three cognitive levels of the revised Bloom's taxonomy. The theoretical framework of authentic learning mirrors real-world relevance with authentic activities from multiple perspectives and provides the opportunity for learners to reflect on the learning process. An exploratory qualitative case study design was used in this inquiry and qualitative data was generated from individual and focus-group interviews and observation. Findings indicated that the participants (six learners and their teacher) had positive experiences in completing the authentic online assessment test of basic accounting content knowledge. However, learners still struggled to successfully deal with calculations and also showed a lack of knowledge and understanding of the basic concepts of the subject. Most significantly, this paper aims not to "prove that learning has improved" but rather that the use of an online assessment tool (QuestBase) within the theoretical framework of authentic learning and assessment reflects the real-life context of learners.
\end{abstract}

Keywords: Accounting, authentic learning, authentic online assessment, Bloom's taxonomy, QuestBase, Secondary school. 


\section{INTRODUCTION}

Teaching and learning of Accounting is intended to develop learners' knowledge, skills, values, attitudes and ability to make meaningful and informed personal and collaborative financial decisions in economic and social environments (Department of Education [DoE], 2003). When learners know the fundamental financial transactions as well as the analysis, interpretation and communication of financial statements, they will be able to understand the fundamental concepts regarding basic accounting principles and practice (Department of Basic Education [DBE], 2011). For Singh, Chauhan and Singh (2016), accounting concepts mean the basic assumptions and rules and principles which work as the basis of recording of business transactions and preparing accounts. Hence, Myers (2016) strongly maintains that learners are firstly to be introduced to the conceptual framework and the abstract concepts based on which all financial accounting recording and measurement decisions are made, given the accrual basis of accounting, where mastery over the procedures of investigation is required. Therefore, to be able to solve an accounting problem, learners need to acquire a specific way of looking at a problem. They need to know and understand theoretical concepts by working through problems and exercises until they reach a point of "expertise" (Maton, 2011). Subsequently, they will be able to understand the fundamental concepts, analyse, interpret and communicate financial statements of the basic accounting principles in practice, that is, in a real-life context. As stated by Crittenden and Crittenden (2014), Accounting reflects economic, social, political, cultural and other local environmental conditions and, is the basis for development of an emerging economy. This could lead learners to become entrepreneurs that can contribute to economic development by facilitating the reallocation of resources from less to more productive uses (Acs \& Storey, 2004).

However, South African learners are failing to acquire the necessary skills for the real-life work environment (Jameel \& Hamdan, 2015). The DBE (2015) points out the three general factors that contribute to learners not achieving better results in Accounting in 2015. These are, firstly, the inability to identify relevant information; that is, weaker learners appear to be disadvantaged by being unable to strategically identify relevant information - they would be distracted by less important items while ignoring significantly more relevant and pertinent information. Secondly, learners are unable to accurately address the requirements of questions; that is, weaker learners provide incomplete or unclear responses to questions. Finally, they are unable to successfully deal with certain calculations involving such concepts as positive/negative signs, rands/cents, percentages and ratios. Bojuwoye, Moletsane, Stofile, Moolla and Sylvester (2014) assert that learners' poor performance in Accounting is attributable to poorly trained teachers.

In the study done by Manda (2014) have identified teachers' lack of adequate subject knowledge and problems of curriculum implementation strategies as contributing to learners' low pass rates. According to Modise (2016), the subject content knowledge and pedagogical knowledge of most South African teachers is poor and that this is a major cause of inadequate learner achievement in Accounting. The lack of subject matter content knowledge of teachers in the teaching and learning process negatively affects teaching and learning and teachers' lack of essential knowledge and skills points to inadequate teacher training, contributing to learners' poor performance in a subject (Jadama, 2014; Manda, 2014). Subsequently, Kuhn, Alonzo and Zlatkin-Troitschanskaia (2016) point out that the teaching of Accounting has shown that teachers need a profound support during their professional training in order to acquire subject content knowledge and skills of designing assessment tasks that will enable their learners to perform and achieve best in the learning process.

In a way of supporting teachers in their teaching profession, the DoE (2004) formulated an alternative form of assessment from paper-based to electronic, using online assessment to assess learners' understanding of content knowledge of any topic (DoE, 2007). Assessment is a crucial element for effective learning and the design of assessment activity is critical, and properly aligning the assessment to the learning outcomes can produce a constructive learning practice (Biggs \& Tang, 2011). Consequently, Baleni (2015) asserts that the design of online assessment must serve the intended purpose, that is, to assess learners' learning in a subject and as such, they must see the value or the benefit in the assessment activity.

Benefits of online assessment are that it gives learners different ways to learn and to demonstrate their learning, facilitates timely formative feedback and builds learners' understanding of the content they have learnt (Baleni, 2015). An online assessment has a rich interface which has the potential to be delivered at various speeds and levels according to the specific needs of the individual (Noyesa \& Garland, 2008). Kearsley (2000) points out that all students' responses can be recorded, providing a wealth of data to analyse and assess their performance. For Al-Amri (2009), online assessment assists test developers to provide the same test conditions for all examinees, regardless of the test's population size. Mostly students praise online assessment in discussion forums as informative and guiding in concepts dealt with in class (Baleni, 2015). Importantly, well-designed online assessments, including multiple choice questions, allow 
assessment of higher cognitive functions, such as critical thinking and analysis skills (Draper 2009; Leung, Mok \& Wong, 2008). It has been revealed that students learning for a multiple-choice assessment concentrate on understanding and comprehension (Leung, et al., 2008) of the content knowledge. Nonetheless, Al-Bataineh, Anderson, Toledo and Wellinski (2008) acknowledge most of the online assessments or computer technology used by teachers is designed without a theoretical framework to scaffold learners' understanding of content knowledge for meaningful learning experiences.

\section{THEORETICAL FRAMEWORK FOR THE DESIGN OF AN ONLINE ASSESSMENT}

A lack of theoretical expertise in the design of online assessments limits researchers' or teachers' vision of what might be accomplished with computer technology in an educational context (Selfe, 1990). Unequivocally, the function of a theoretical framework is to inform the rest of the design to help teachers to assess and refine their goals and develop a realistic assessment task (Hale \& Napier, 2013) that mirrors real-life experiences of learners for meaningful learning experiences in the learning process. This study employed the characteristic of authentic learning as a theoretical framework in the design of an online assessment. Authentic learning is learning through applying knowledge in real-life contexts and situations, and allows learners to make connections between the school setting and the demands of their broader communities (Mantei \& Kervin, 2009). Herrington and Oliver (2000) articulate that useable knowledge is best gained in learning environments that feature the characteristics of authentic learning as presented in Table 1.

Table 1. Characteristics of authentic learning (adapted from Herrington \& Oliver, 2000).

\begin{tabular}{|c|c|c|}
\hline \multicolumn{2}{|c|}{ Characteristics of authentic learning } \\
\hline & Key constructs & A brief explanation in context \\
\hline 1) & Authentic context & $\begin{array}{c}\text { Authentic context embedded in the way the knowledge will } \\
\text { be used in real life }\end{array}$ \\
\hline 2) & Authentic activity & Authentic activity that people do in the real world of practice \\
\hline 3$)$ & $\begin{array}{c}\text { Multiple } \\
\text { perspectives }\end{array}$ & $\begin{array}{c}\text { The opportunity for learners to examine the task from } \\
\text { different perspectives using a variety of resources }\end{array}$ \\
\hline 4$)$ & Reflection & $\begin{array}{c}\text { The opportunity to reflect and involve learners' beliefs and } \\
\text { values }\end{array}$ \\
\hline 5$)$ & $\begin{array}{c}\text { Interdisciplinary } \\
\text { Activities encouraging interdisciplinary perspectives and } \\
\text { building of expertise in other well-defined fields }\end{array}$ \\
\hline 6$)$ & $\begin{array}{c}\text { Authentically } \\
\text { assessed }\end{array}$ & $\begin{array}{c}\text { Assessment that is seamlessly integrated with learning in a } \\
\text { way that reflects how quality is judged in the real world }\end{array}$ \\
\hline
\end{tabular}

Authentic contexts in the classroom are more than simple examples from real-world practice that act as illustrations of a concept being taught. The context needs to be all embracing, to provide the purpose and motivation for learning (Herrington \& Kervin, 2007). Accordingly, authentic learning requires students to complete tasks that would be carried out in the real-world workplace and it means that theoretical knowledge or concepts are applied to scenarios which are akin to those found in reality (Simpson, 2016) using technologies as cognitive tools. Cognitive tools mean "technologies, tangible or intangible, that enhance the cognitive powers of human beings during thinking, problem solving, and learning" (Jonassen \& Reeves, 1996, p. 693). Such an approach is cognitively authentic, as students are made to think deeply about the content that they are learning and are subsequently able to discover new knowledge (Herrington \& Herrington, 2006).

Enabling learners to use their cognitive structures enables them to achieve a deeper level of understanding in the learning task (Craig, 2016) within an authentic online assessment task that is designed according to the six levels of cognitive processes of the revised Bloom's taxonomy, namely remembering, understanding, applying, analysing, evaluating and creating (Anderson \& Krathwohl, 2001). In the context of this study, only the first three levels of the revised Bloom's taxonomy were used with their related action verbs in the design of the online assessment as follows: 
- Remembering with action verbs - define, identify, name, recall;

- Understanding with action verbs - choose, classify, give in one word; and

- Applying with an action verb - calculate.

These lower levels of skills are required to be formed before progressing to the higher levels as they underlie critical thinking to produce the desired effects of incremental learning in teaching in a school subject (Nkhoma, Lam, Richardson, Kam \& Lau, 2016). Accounting content was generated from the Annual Teaching Plan for Term 1 as stipulated in the Curriculum and Assessment Policy Statement (DBE, 2011), which stipulates 10 weeks of teaching and learning. Learners were expected to remember facts, understand concepts and apply procedures of basic accounting content knowledge.

The design of accounting online assessment was done using QuestBase software, an online quiz creator that allows teachers to create tests and assessments with powerful customisable features, such as question banks (multiple choice, fill in blanks, true/false, short, essay-type answer, or any combination of these modes), pictures, equations, scores and feedback. It is a form of highly interactive and self-evaluating assessment (SmartLite Software, 2013). QuestBase is a web service with an unlimited number of questions, with no limit to the number of learners taking the assessment, and the created assessments can be carried out on various platforms, such as any personal computer or mobile device.

\section{CONTEXT OF THE STUDY}

The study was conducted at a public secondary school in Gauteng Province, South Africa. The school has internet connectivity, a data projector and computer laboratory with 40 computers. The school also received 40 new computer tablets and headphones provided by the Gauteng Department of Education. All the teachers and learners in the school have basic computer skills. 34 learners with their teacher participated in the study and before they completed the online assessment, they were orientated about: i) multimedia resources, such as playing the video clip with sound with their headsets on or using the magnifying glass to expand a picture for content presentation; ii) how to use the built-in calculator instead of a battery-operated calculator; iii) how to submit the completed assessment online; and iv) how to check the feedback and results provided after submission. Ethics approval was obtained through the school, Gauteng Department of Education and the Johannesburg University's Faculty of Education Academic Ethics Committee. The research question guiding this study was: What are learners' and their teacher's experiences of the design of authentic online assessment in understanding basic accounting content knowledge?

\section{RESEARCH DESIGN}

A qualitative case study as a research design was used in this enquiry as it reflects the real-life context (Yin, 2014) of the participants. Hence, an exploratory case study was employed to better understand the design of an online assessment with theoretical insights. Consequently, the unit of analysis (the case), was the design of an authentic online assessment test in understanding of basic accounting content knowledge of learners.

A qualitative data was generated from interviews and observation. Open-ended semi-structured individual and focus-group interviews were used to elicit precise information from the participants, which allowed them to express their responses in their own words. After learners completed online assessment test, a focusgroup interview was conducted with six of them and their teacher was also interviewed individually after learners' interviews. A tape-recorder was used during interviews. Learners were also observed during the completion of online assessment test and the observation data was based on their interaction with QuestBase software and their experiences in answering the accounting content designed in authentic learning and teaching context.

Data from the interviews and observation was analysed through content analysis in order to reduce it into manageable codes, themes and categories. As Bryman (2004, p. 542) avows, content analysis allows "categories to emerge out of data and on recognizing the significance for understanding the meaning of the context in which an item being analyzed appeared". The categories generated during data analysis were about learners' and their teacher's experiences on the design of authentic online assessment in understanding basic accounting content knowledge.

\section{RESEARCH FINDINGS}

The findings which emerged from the learners' and their teacher's experiences on the design of authentic online assessment in understanding basic accounting content knowledge are presented in relation to the 
characteristics of authentic learning in Table 1 and the first three levels of the revised Bloom's taxonomy. Fictitious names were assigned to each learner in order to protect their identities. Six categories generated from interviews supported by observation data are discussed below.

\subsection{The Design Of Authentic Online Assessment Enabled Learners To Remember, Understand And Apply Basic Accounting Concepts That Mirror Authentic Real- Life Context}

Learners' and their teacher's experiences on the design of authentic online assessment in understanding basic accounting content knowledge in authentic context were expressed as follows:

Dumi Pictures in the assessment are for the business that we know like of Ndondosa Pizza restaurant. I remember there are different malls in our area ... So when you answer looking at the pictures it is easy because you just remember what you have seen already and it is something that you know. I think it is nice to present accounting assessments using real picture and videos, it should be done more often.

Boity Yes. The pictures with words on the computer screen made me to understand better, for example, the terms that we use in accounting like ... non-current assets. So I was able to answer the assessment easily.

Enhle Sometimes the terminology is current assets when we classify things like ... money in the bank, cash float and pizza ingredients ... so pictures with words assist in understanding the terminology because it is confusing sometimes.

Teacher Learners who understood ... more so with the assistance of the images rather than words alone displayed on their computer screens ... like an extract with videos which is already making it real life because of the system that is used worldwide when handling petty cash in a business.

Cebile You click on the magnifying glass. It helped me to understand the accounting concepts a lot because what I have seen is what takes place every day in businesses around.

Andile Also the person talking in the video was explaining the terms which I did not know and showing pictures of petty cash. I found it easy because I could play the video again to understand the concepts better and then answer the questions. I know a situation like this in my neighbours' business.

Findings from the observation data also indicated that learners were engaged in answering the assessment test that represented the real-life context as a result of the graphics and video with voice recording included in the design of the authentic online assessment.

Learners were asked to reflect on their answers about the authentic assessment test and the some of them found questions on calculations difficult to answer but others found the assessment helpful:

Feni The calculations were difficult because you had to calculate first ... I tried to calculate the amount but did not get it right.

Andile The petty cash video was difficult ... We were not taught that in class and I found it difficult to calculate the amount. The one ... about being an auditor was difficult because I have to think.

Dumi I found that the moving pictures in the video and the explanation gave more information on what petty cash and the imprest amount is about. I was able to calculate the imprest amount.

Enhle The one of Kitty Kat scenario, you've got to think hard like an auditor to choose the right answer ... This assessment is interesting because it shows us that in real life auditors, financial advisors and accountants are important people to help you run your business smart. 
The teacher shared his learners' difficulties in doing calculations and needing to think before answering questions:

Teacher The scenario question on internal control, I can say that was higher-order thinking because it just needed some kind of reasoning, apply procedures in a business. Learners often struggle with financial accounting because there are a number of aspects to remember.

\subsection{Assessing Learners' Content Knowledge Within Authentic Online Assessment Enabled Them To Carry Out Tasks Based On The Real World Of Work Of Accountants And Business People}

A fictitious scenario was complex enough for learners to encounter it in a real business environment. The teacher experienced how learners would do as accountants in a real-life context:

Teacher With the authentic online scenario, we have a situation on decision making by the auditor like the one describing internal control procedures to be implemented by management in the business to avoid stock loss or theft. This was really professional. This is a good initiative in accounting studies.

Corroborating the teacher's experience, two learners pointed out that:

Boity As accountants, we used terms like debtors as people who owe the business money and I know the difference between income and expenses. You must also know which account is debited or credited so that you use it correctly.

Enhle Accountants use, for example, money in the bank and cash float you classify as current assets like it is used in this assessment activity and you must know that and not confuse it with non-current assets.

In answering the question: Did the authentic online assessment ensure that learners utilised the workplace concepts covered in the Accounting syllabus to produce solutions that would be acceptable in the workplace? The teacher's reply was:

Teacher Yes, reasons being we had a situation to act like an accountant assisting the business owner with usage of correct accounting concepts and to separate the business accounts according to generally accepted accounting principle. For example, to identify the different types of businesses, current assets, non-current assets, expenses, including the definitions of the basic accounting concepts.

\subsection{Authentic Online Assessment Activity Developed Learners' Multiple Perspectives Used By Accountants In Their Workplace Environment}

The use of computers (QuestBase) in Accounting created the opportunity for learners to perform as accountants or business people in the real world from multiple perspectives:

Andile $\quad$ Yes ... especially when we do accounting using computers like now... it feels good. In many companies people use computerised accounting.

Cebile Accountants use computers all the time when they do their work in the office and at home like doing business transactions online and sending e-mails to clients.

Boity During our normal class we use battery-operated calculators for activities but now with this online activity we can use the calculators that are built in the computers for our calculations and to solve problems and we don't have to bring our old battery calculators anymore to class.

Enhle Some of us used tablets. So I have seen business people using tablets these days. They 
carry them everywhere to run their business, such as, buying online and connecting with clients.

Dumi I also saw classmates using cell phones to write the same online assessment as we did. So you can still do this assessment using a cell phone.

Feni Our teacher used his cell phone, it means I can do business at home using a cell phone when connected to Internet, like online, cell phone and Internet banking.

In substantiating what learners have experienced in learning accounting content with technological devices, the teacher experienced that:

Teacher These days you find that many businesses use technology to run their affairs, so using computers in accounting gives learners that feel of being in the professional world already. Accounting could be made simpler and more practical and professional using computers, tablets and cell phones.

\title{
5.4. The Immediate Feedback Embedded Within Authentic Online Assessment Enabled Learners To Reflect On Their Performance And About Their Future Prospects
}

\begin{abstract}
Cebile Taking the test online was interesting because it showed me the correct answers and the wrong answers. I can improve my understanding of accounting concepts and terminology and the correct advice to give to my clients.
\end{abstract}

Boity I got all answers correct because I as an auditor, I was able to give right advice to business people like uMi Casa. Auditors apply their minds a lot in order to provide specific auditing procedures because they have the knowledge. The use of this computer gave me an opportunity to check my answer with feedback received on my answer as an expert.

Andile It was fun and interesting. I did not have exposure to computers in accounting at all but I think it is necessary for us to use it to study and also find it useful for my future employment and career.

Enhle I did not have exposure to computers in Accounting at all but I think it is necessary for us to use it to study and also find it useful for my future employment and career.

An authentic online activity that enables learners to reflect on learning develops self-awareness and thinking about the learning process. In responding to this question: "How do you reflect about being given a chance to imitate the task of an accountant in this online assessment activity?" Learners responded that:

Dumi I know the answers now to the questions I did not know before. Solutions are given at that moment instead of a day or two later. I have learnt from this online assessment.

Enhle It shows everything at the end like your percentage mark and the graph shows the answers I got right and wrong in different colours. It is nice and I love it.

In sharing his learners' experiences with immediate feedback through authentic online assessment testing, the teacher experienced that:

Teacher The most interesting part I found is that learners received immediate feedback after completing an assessment activity; this can address their weaknesses they may be having with content immediately. That helps me as a teacher too in order to identify the content gap fast with QuestBase.

Findings from the observational data also indicated that learners enjoyed and were encouraged to complete the assessment test as they were receiving immediate feedback in the process. 


\subsection{Authentic Online Assessment Enabled Learners To Integrate The Learning Of Accounting To Other Subjects}

The authentic online assessment activity was deliberately designed to integrate or apply interdisciplinary perspectives across different subject areas. This was evident from the learners' experiences:

Feni I enjoy accounting because in this assessment activity we also learnt about starting a new business just like we are taught in Business Studies. The method of doing things is similar in these subjects.

Boity Yes, were taught some accounting concepts in EMS [Economics and Management Sciences] and they are also in the test like the different types of businesses. We also learn that in Business Studies.

Enhle I understand the accounting basic concepts better now in this assessment activity because they are related to the real world and apply in other subjects I am studying as well.

In spite of this, the teacher shed some light on certain topics of the accounting curriculum that were either not covered or not adequately taught in grades 8 and 9 :

Teacher Petty cash was introduced in EMS lower grades right ... it was a summary, like, it wasn't detailed enough in lower grades ... but they didn't go in detail like the video explained to them ... their background in EMS wasn't solid - that much so we as educators in grade 10 accounting we are facing problems ... there are certain things they are that ought to have been known in grade 8 and 9 which probably they are struggling with.

\subsection{The Design Of Authentic Accounting Assessment Activity With Questbase Was Seamlessly Integrated To Promote Effective Learning}

In responding to the thought about the design of authentic accounting assessment activity integrated with QuestBase, participants expressed that:

Dumi I find this assessment activity promoting learning because I understood exactly what role accountants do and the problem solving that goes with it and that helped me know how to improve my performance.

Feni This assessment activity made us to be active and to engage with content and learn creatively. We got more information on the side as we went along in the assessment activity than in normal assessment in class to support our understanding of the content.

It is thus evident that the teacher rated highly the design of authentic accounting content as seamlessly integrated with QuestBase:

Teacher I find this assessment activity better than the traditional method, interesting, motivating as well as an opportunity to see if the learners shall have learned some skills and understood the content and representation of their lived experiences or professionalism through their engagement with content in the online assessment activity, unlike just assessing how much they have learned and can produce at the end of a particular period.

Overall, findings from the observation reported that some of the learners showed signs of frustration as they struggled at first to interact with multimedia resources and assistance was provided to them. As the test of accounting content was designed in an online assessment embedded within authentic learning and teaching, more became confident in engaging with the assessment test supported by the computer. Most of them expressed happiness, were comfortable and were motivated to continue with the idea of using a new method of assessment in the form of an online computer based assessment.

\section{DISCUSSION}

The discussion on the findings of six categories are related to and embedded within the characteristics of authentic learning as presented in Table 1 and the first three levels of the revised Bloom's taxonomy. 
The design of authentic online assessment mirrored the real-life context, enabled learners to remember, understand and apply basic accounting concepts: The use of multimedia elements in a scenario helped the learners to easily answer questions as they were able to remember, understand and apply (levels of Bloom's taxonomy) the basic accounting concepts. The scenario enabled them to reflect on accounting concepts (reflection) that were seamlessly integrated with the real world and not separated from the nature of the task (authentically assessed) and as such, embedded in the activity (authentic activity).

Assessing learners' content knowledge within authentic online assessment enabled them to carry out tasks based on the real world of work of accountants and business people: An authentic online scenario (authentic context and authentic activity) enabled the participants to think deeply and to consider (reflect) the significant of accounting as a school subject (interdisciplinary) that can be applied in the real-life situation of a business. So, participants positively experienced that value of the design of the assessment test (authentically assessed) based on accounting concepts that form the language of communication in different types of businesses (multiple perspectives) in real-life environments.

The design of authentic online assessment activity gave learners the opportunity to use various resources accountants use in the workplace environment: The participants acknowledged (reflect) that technological devices (multiple perspectives) are necessary in the work place of accountants (authentic context and authentic activity) and in the business world. Business transactions, calculating, sending e-mails to clients, using the internet for banking in a professional world (interdisciplinary) could be made simpler by computer technology.

The immediate feedback embedded within authentic online assessment enabled learners to reflect on their performance and about their future prospects: Learners reflected and acknowledged that learning Accounting with computers is fun and interesting. Above all, their reflection was more critically projected at future employment (multiple perspectives, authentic context and authentic activity) and possible career choice. As an auditor, one would need to have knowledge about specific auditing procedures (interdisciplinary) in order to be able to give the right advice to business people. Receiving immediate feedback helped to identify (reflect) the weaknesses and the content gaps that they were struggling with in the learning process.

Authentic online assessment testing enabled learners to integrate the learning of Accounting to other subjects: Learners confirmed that they enjoyed completing the assessment, as they then also understood (reflect) concepts related to other subjects like Business Studies and EMS (interdisciplinary, multiple perspectives, authentic activity and authentic context).

The design of authentic accounting assessment activity with QuestBase was seamlessly integrated to promote effective learning: The online assessment test was better than the traditional methods of assessment or normal assessment in class to support learners' understanding of the content. The participants experienced and acknowledged (reflection) that the seamlessly integrated design of authentic assessment activity with QuestBase supported them in understanding problem solving (authentic context, authentic activity and multiple perspectives) and in improving their performance in subject.

Consequently, using computer technology tools in Accounting in schools within the authentic learning context and taking into account the cognitive levels of Bloom's taxonomy will not only develop learners' important skills such as communication, interpersonal skills and critical and analytical thinking skills but also develop their professional accounting skills that can make profound contribution to knowledge in emerging economies (Elsaadani, 2015). As Ganda, Ngwakwe and Ambe (2014) point out, this investigation is important considering the importance of education toward social and economic development within the South African context and beyond, and that learners must be properly prepared to participate in the world economies by becoming entrepreneurs.

\section{CONCLUSION}

In this paper, the design of online assessment with QuestBase software was underpinned by the six characteristics of the theoretical framework of authentic learning and the first three cognitive levels of the revised Bloom's taxonomy. The theoretical framework of authentic learning, including cognitive levels of Bloom's taxonomy, was used in order to give us a better perspective of our research approach and the underlying assumptions influenced our research design (Caliendo \& Kyle, 1996). For a lack of a theoretical framework in research design limits our vision of what might be accomplished with computer technology in a broader social and educational context (Mishra \& Koehler, 2006). Despite the fact that the participants had a positive experience in understanding of basic concepts of accounting, learners still need to be supported in order to improve their performance in the subject. 


\section{LIMITATIONS}

Limitations in this study are firstly, that due to the limited time the participants had to complete the assessment test only six characteristics of authentic learning were used out of a possible 10. The other four characteristics that were not included are authentic activity investigated and produced over a sustained period of time; authentic products to be produced collaboratively; authentic activity with polished products and authentic activity with diversity of outcome (Herrington \& Oliver, 2000). Secondly, only the first three cognitive levels of the revised Bloom's taxonomy were used in this study, and not the other three levels, namely analysing, evaluating and creating, which could have shed light on the depth of learners' understanding of the basic content knowledge. Lastly, if learners had initially been taught through characteristics of authentic learning, their experiences could have been significantly different about their understanding of basic accounting content knowledge with computer technology (QuestBase).

Based on the above limitations of this study, a further research could be done that will use all the 10 characteristics of authentic learning, including all the six cognitive levels of the revised Bloom's taxonomy in the design of assessment test in order to have a deeper insight into the participants' experiences of an authentic online assessment test in the understanding of basic accounting content knowledge.

\section{REFERENCE LIST}

Acs, Z \& Storey, D. (2004). Introduction: Entrepreneurship and Economic Development. Regional Studies, $38(8)$.

Al-Amri, S. (2009).Computer-based testing vs. paper-based testing: establishing the comparability of reading tests through the evolution of a new comparability model in a Saudi EFL context. Unpublished doctoral dissertation. University of Essex, England.

Al-Bataineh, A, Anderson, S, Toledo, C \& Wellinski, S. (2008). A study of technology integration in the classroom. International Journal of Instructional Media, 35 (4).

Anderson, L \& Krathwohl, D.A. (2001). Taxonomy for learning, teaching and assessing: A revision of Bloom's Taxonomy of Educational Objectives. New York: Longman.

Baleni, Z.G. (2015). Online formative assessment in higher education: Its pros and cons. The Electronic Journal of e-Learning, 13 (4).

Biggs, J \& Tang, C. (2011).Teaching for Quality Learning at University. Maidenhead: Open University Press.

Bojuwoye O, Moletsane M, Stofile S, Moolla, N \& Sylvester, F. (2014). Learners' experiences of learning support in selected Western Cape schools. South African Journal of Education, 34 (1).

Bryman, A. (2004). Social research methods (2nd ed.). New York: Oxford University Press.

Caliendo, S. M \& Kyle, W. C. (1996). Editorial: Establishing the theoretical frame. Journal of Research in Science Teaching, 33 (3).

Craig, T.S. (2016). The role of expository writing in mathematical problem solving. African Journal of Research in Mathematics, Science and Technology Education, 20 (1).

Crittenden, C.A \& Crittenden, W.F. (2014). The accounting profession's role in corporate governance in frontier markets: A research agenda. Organizations and Markets in Emerging Economies, 5 (5).

Department of Basic Education. (2011). National Curriculum Statement. Curriculum and Assessment Policy Statement, Accounting. Further Education and Training Phase Grades 10-12. South Africa. Pretoria: Government Printer.

Department of Education. (2003). National Curriculum Statement Grades 10-12 (General) Accounting. Pretoria: Government Printer.

Department of Basic Education. (2015). National Senior Certificate Examination 2015, Diagnostic Report. Pretoria: Government Printer.

Department of Education. (2007). Guidelines for Teacher Training and professional Development in ICT. South Africa, Pretoria Government Printer.

Department of Education. (2004). White Paper on e-Education: Transforming Learning and Teaching through Information and Communication Technologies. Pretoria: Government Printers. 
Draper, S. W. (2009). Catalytic Assessment: Understanding how MCQs and EVS can Foster Deep Learning. British Journal of Educational Technology, 40 (2).

Elsaadani, M. (2015). Information and Communication Technology skills' sufficiency of Egyptian accounting graduates. International Journal of Advanced Information Technology, 5 (1/2).

Ganda, F, Ngwakwe, C.C \& Ambe, C.M. (2014). Independent Research and a Deep Approach to Learning of Accounting Concepts. Students' View, 5 (6).

Hale, S \& Napier, J. (2013). Interpreting research methods: A practical resource. London: Bloomsbury.

Herrington, A \& Herrington, J. (2006). What is an authentic learning environment? In A. Herrington \& J. Herrington (eds), Authentic learning environments in higher education. Hershey, PA: Information Science Publishing.

Herrington, J \& Kervin, L. (2007). Authentic learning supported by technology: 10 suggestions and cases of integration in classrooms. Educational Media International, 44 (3).

Herrington, J \& Oliver, R. (2000). An instructional design framework for authentic learning environments. Educational Technology Research and Development, 48 (3).

Jadama, L.M. (2014). Impact of subject matter knowledge of a teacher in teaching and learning process. Middle Eastern \& African Journal of Educational Research, 7 (1).

Jameel, S.H \& Hamdan, A. (2015). Effects of student's attendance on accounting student's performance. International Journal of Business and Management Review, 3 (5).

Jonassen, H \& Reeves, T.C. (1996). Learning with technology: Using computers as cognitive tools. In $\mathrm{DH}$ Jonassen (Ed.), Handbook of research for educational communications and technology, (1st ed.). New York: Macmillan.

Kearsley, G. (2000). Online Education: Learning and Teaching in Cyberspace. Toronton, ON: Wadsworth.

Kuhn, C, Alonzo, A.C \& Zlatkin-Troitschanskaia, O. (2016). Evaluating the pedagogical content knowledge of pre- and in-service teachers of business and economics to ensure quality of classroom practice in vocational education and training. Empirical Research in Vocational Education and Training, (8) 5.

Letshwene, M.J. (2014). Improving grade 10 accounting teachers' competencies in the Ekurhuleni District of the Gauteng Province. Unpublished MEd dissertation. Pretoria: University of South Africa.

Leung, S. F, Mok, E \& Wong, D. (2008). The Impact of Assessment Methods on the Learning of Nursing Students. Nurse Education Today, 28 (6).

Manda, D.C. (2014). An Investigation on the Shortage of Accounting Teachers and Its Effect on High Schools Pass Rates in Vhembe District Limpopo Province, South Africa. Kamla-Raj - J Soc Sci, 41(3).

Mantei, J \& Kervin, L.K. (2009). "Authentic" learning experiences: what does this mean and where is the literacy learning? In Moult, A (eds), Bridging Divides: National Conference for Teachers of English and Literacy, 2009, p 1-16, Hobart, Australia: Australian Association for Teaching of English/Australian Literacy Education Association.

Maton, K. (2011). Theories and things: The semantics of disciplinarity. In F. Christie \& K. Maton (eds.), Disciplinarity: Functional linguistics and sociological perspectives (pp. 62-84). London: Continuum.

Mishra, P \& Koehler, M.J. (2006). Technological Pedagogical Content Knowledge: A Framework for Teacher Knowledge. Teachers College Record, 108 (6).

Modise, A.M. (2016).Pedagogical Content Knowledge Challenges of Accounting Teachers. Kamla-Raj - Int J Edu Sci, 13(3).

Myers, L.P. (2016). Knowledge structures and their relevance for teaching and learning in introductory financial accounting. South African Journal of Accounting Research, 30 (1).

Ngwenya, J.C \& Maistry, S.M. (2012).Teaching and assessment in accounting: An exploration of teachers' experiences in a rural KwaZulu-Natal school. Journal of Social Sciences, 33 (1).

Nkhoma, M, Lam, T, Richardson, J, Kam, K \& Lau, K. H. (2016). Developing case-based learning activities based on the revised Bloom's Taxonomy. Informing Science \& IT Education Conference (In SITE) 2016, 85-93. Available at http://www.informingscience.org/Publications/3496. Accessed 28 August 2016. 
Noyesa, J.M \& Garland, K.J. (2008). Computer- vs. paper-based tasks: Are they equivalent? Ergonomics, 51 (9).

Ozden, M. (2008). The effect of content knowledge on pedagogical content knowledge: The case of teaching phases of matters. Educational Sciences: Theory \& Practice, 8 (2).

Selfe, C. (1990). Technology in the English classroom: Computers through the lens of feminist pedagogy. In C. Handa (Ed.), Computers and community: Teaching composition in the twenty-first century (pp. 118139). Portsmouth, NH: Boynton/Cook.

Simpson, J. (2016). Authentic Learning - Does It Improve Pass Rates and Student Satisfaction? Journal of Perspectives in Applied Academic Practice, 4 (2).

Singh, S.K, Chauhan, S \& Singh, S.K. (2016). Accountancy for Class-XI (Commerce). SBPD Publications. Agra in Uttar Pradesh, India.

SmartLite Software. (2013). QuestBase. Available at http://download.cnet.com/QuestBase/3000-2051_475851492.html. Accessed 15 June 2015.

Steenkamp, L.P, Baard, R.S \& Frick, B.L. (2010). Factors influencing success in first-year Accounting at a South African university: The profile of a successful first-year Accounting student. South African Journal of Accounting Research, 23 (1).

Yin, R.K. (2014). Case study research: Design and Methods (5th ed.). Los Angeles, CA: Sage. 